\title{
Management Strategy to Achieve Competitive Advantages in Commercial Companies and Improve Productivity, Employee Loyalty and Customer Service Quality: Spirituality in the Work Environment
}

\author{
Segundo Castro-Gonzáles \\ University of Puerto Rico \\ Elimari Ríos Pérez \\ Albizu University
}

According to recent research work, spirituality in the workplace is strategically becoming a competitive advantage for companies. The main objective of this research is to analyze the effect of spirituality in commercial companies, by measuring the perception of satisfaction, productivity and commitment of employees, and the consequences that these directly have on the satisfaction and loyalty of customers of these commercial facilities. The methodology used for measuring the spirituality levels of the workers was through frequency analysis and to solve the relationship between spirituality vs. internal service quality and the external service perception, Structural Equation Modeling was used through the novel technique of "partial least squares" (SEM-PLS).

Regarding the practical implications of this study we can see that if businessmen encourage a work environment in their companies where good levels of spirituality prevail, they will probably have higher productivity, more loyalty and satisfaction of their workforce, as well as high levels of customer loyalty and will have more satisfied customers for the services received by their employees.

Keywords: workplace spirituality, productivity, job loyalty, job satisfaction, customer service quality, SEM$P L S$

\section{INTRODUCTION}

In recent years, the spirituality of workers and the relationship with the workplace has been gaining visibility and interest from both employees and employers, and even in the academic literature, this concept has increased considerably. Given the fact that in different work circumstances, the diverse benefits that spirituality can provide to different organizations have been studied and demonstrated. For this reason, it has aroused interest in groups of professionals dedicated to strategic management and human resources managers. However, it is noticed that people want to practice their spirituality at work but are afraid to do so because it can lead to conflict and a false perception, as it tends to be generally related to the concept of religion. As we know, it is neither advisable nor encouraged to talk a lot about religion or religious groups in the workplace. On the other hand, employees do not have the space required to express their workplace 
spirituality because management does not have the scientific certainty that a position in favor of this type of practice will result in improved productivity, satisfaction and loyalty of their employees and customers. For these reasons, the results of this research will undoubtedly contribute to knowledge about the topic and to the development of future research, which is expected to result in the creation of training programs and strategies that can be implemented in the practice of Human Resources, as well as in other disciplines.

When a detailed analysis of spirituality is made, it has been found that this topic is an encompassing concept that has been widely reviewed and for which there is a great variety of meanings. Rozitchner (2012), for example, defines spirituality as "a path of search and personal growth, which overcomes the usual perspective of reproach and dissatisfaction towards existence and transforms it into a position of acceptance, understanding, development and discontent". In this line of thought, Sant-Rajinder (2010) proposes that spirituality is a science that seeks to answer questions about who we are, why we are here, where we come from and where are we going after we die.

However, for this research, we need a definition that can describe and relate spirituality in the workplace and that does not mix the concept with religion as many other authors usually do. With that conceptualization in the making, we adopt the definition of Mitroff and Alpaslan (2099) who conducted an empirical study with human resource executives and company managers in the United States about spirituality in the workplace. These authors concluded that spirituality is not formal, organized or structured, but rather they indicate that spirituality is above religious denominations, above churches, above religious groupings and that it includes all types of people, that it does not try to gain followers, and that it is the essential source that provides meaning and purpose to life (Mitroff and Alpaslan, 2099).

Thus, the interest in this study topic arises, first of all, from an effort to separate the concept of spirituality from that of religion, which are often confused with each other. For this reason, we consider that it is important to study about the relationship that spirituality practices can have at work, and how this important component in the human being and therefore in the worker can positively or negatively affect the performance of employees. Therefore, we would expect a direct correlation between the worker's spirituality and his/her direct contribution to the success of a company. Most of the authors under review affirm that spirituality could become an important management strategy of this century in order to gain competitive advantages for companies. Chawla \& Guda (2013), indicate that an important part of human resource management is to keep the workplace pleasant for employees and, at the same time, profitable or profit-generating, establishing a balance between the goals of the company and the personal goals of its human resources. Undoubtedly, this is a task that is becoming increasingly difficult and generates the need to innovate in human resources practices, to seek new tools in order to keep employees motivated and more productive (Chawla \& Guda, 2013).

Consequently, the objectives of this research were: 1) To measure the spirituality levels of employees of retail companies in Puerto Rico; 2) To analyze the spirituality effect on employee satisfaction, employee commitment, and labor productivity of employees of retail companies in Puerto Rico; and 3) To evaluate the spirituality effect on customer satisfaction and loyalty of customers of commercial companies in Puerto Rico. This article is structured as follows: it begins with a literature review section, then covers the theoretical framework, proposing a model of the author's creation, then describes the methodology to be used, followed by a section with the results of the research, and finally covers the most important conclusions of this work.

\section{LITERATURE REVIEW}

The spirituality concept in the workplace is rarely studied in Puerto Rico, in Latin America and also internationally. Although Latin countries have an important religious relevance, spirituality has not been fully covered. However, spirituality is gaining international momentum, and around the world there is some published research proposing that there is a positive correlation between employee spirituality and corporate success (Pérez, 2007). Other authors state not only that the inclusion of spirituality at work is important, but also that Spirituality in the workplace environment will be a new strategic tool for leaders in the twentyfirst century to achieve competitive advantages for their organizations (Pérez, 2007). On the other hand, it 
is noted that in academia, the concept of spirituality has been on the rise in recent years, and more and more people are becoming interested in its study, both at a personal, academic and professional level(Counted et al., 2018; Daniel, 2019).

\section{SPIRITUALITY AT WORK}

Most authors who have spoken about spirituality agree that, although they are often confused, the concepts of spirituality and religion are different. Vilaca (2012) is one of the authors who highlights these differences and agrees that spirituality should be an integral part of organizations, stating that to omit the spiritual reality of individuals is to deny a fundamental component of human behavior, this proposal is made as part of her doctoral thesis on organizational spirituality and psychological capital. Wax (2005) includes the historical definitions of spirituality and religion and explains how one concept has been separated or differentiated from the other. For the purposes of its study, spirituality refers to inner beliefs and experiences based on the conviction that there is a spiritual universe beyond the visible, while religion is defined as affiliation and association with public institutions (Wax, 2005).

Mitroff \& Alpaslan (2009) emphasize their intention not to mix the concept of spirituality with that of religion. Spirituality is understood as the fundamental feeling of being interconnected with one's whole self, with others, and with the entire universe. On the other hand, in the longitudinal study conducted by professors Angelita Escobar and Ana M. Viader among incoming students at Universidad del Este, the difference between spirituality and religion is highlighted. More than $70 \%$ of the participants stated that we are all spiritual beings and that most people can grow spiritually without being religious (Escobar \& Viader, 2013).

Historically, spirituality, although recognized as an essential part of being human, was not invited to participate in the workplace and employees were not allowed to express themselves in that sense. But this is changing because more and more authors are expressing themselves favorably regarding this topic. For example, Argandoña (2014) highlights the need that has been developing in recent years to include the spiritual dimension in the workplace. The author explains that "it is about recognizing the variety of dimensions of the human person, who has a bodily and a spiritual reality, including his/her capacity to know and to do, his/her feelings and emotions, attitudes, values and virtues". People come to the workplace with both material and spiritual needs, which they try to satisfy by performing their jobs and interacting with their co-workers. This is precisely why the author not only addresses workers, but also managers, and urges them to take into consideration the spiritual dimension of their employees, and not as an option, but as a duty (Argandoña, 2014).

Damiani (2016), on the other hand, points out that the search for spirituality, for that link between the person and the totality (understood as the universe, life or God), is a fundamental aspect of life. As mentioned above, the topic of spirituality has been on the rise in recent years, and more and more people are becoming interested in its study, both personally, academically and professionally. In times of economic difficulty and even more so in this COVID-19 pandemic that we have had to live, uncertainty grows among workers, who seek through spirituality, to manage conflicts and situations related to the labor aspect. Damiani (2016) states that spirituality is a tool for workers to feel comfortable with their work, which results in better performance. An employee who feels satisfied with the working conditions and environment will be more receptive about meeting or exceeding the expectations of his/ her job, which is beneficial to the company. Among the benefits highlighted by the author are: higher employee productivity, increased tolerance level related to customer service, and personal independence and self-realization (Damiani, 2016).

In addition, Escobar \& Viader (2013) state that spirituality at work is a topic that is increasing regarding its study and dissemination. Spirituality in the work context is perceived as an intangible asset, which participants see as something that provides meaning, purpose, and generates a community sense. Spirituality, they state, is a concept that correlates with the work behavior of employees and with the company's productivity (Escobar \& Viader, 2013). On the other hand, Robles (2011), found that 64.6\% expressed that spirituality is relevant in the workplace, and $56.9 \%$ felt that it is an appropriate topic to 
discuss at work. Other significant findings in the research indicate that "the good that an organization does for its community will be returned in profits" $(76.5 \%)$, "spirituality can make employees more productive" (76\%), "spirituality helps in making decisions at work" (72.6\%), and that "spirituality could help to give meaning, significance and purpose to work" (78.4\%) (Robles, 2011).

In 2007, José Armando Pérez of Carlos Albizu University, Puerto Rico, conducted a study aimed at identifying the perceptions of a group of employees about spirituality and its relevance at work. The study included the participation of 250 employees, with the result that for most of the participants the spiritual dimension is important, and that their jobs should provide them with spaces for their personal and spiritual development (Pérez, 2007). Other findings that emerged from the study are: highly spiritual people have better performance at work, a person who is highly spiritual demonstrates it through his/her actions, a high level of spirituality is a quality that every leader should have, and that employee assistance programs should consider the spiritual dimension of the individual (Escobar \& Viader, 2013; Pérez, 2007 and Robles, 2011).

\section{EMPLOYEE SATISFACTION, PRODUCTIVITY AND ENGAGEMENT IN AN ORGANIZATION AS COMPONENTS OF INTERNAL EMPLOYEE SERVICE QUALITY}

According to the research conducted by Gil (2007), he states that since the eighties, the perception of executives towards employees in organizations has evolved from representing only a cost to be minimized, to being valued as the most important resource in the company and which must be optimized to achieve their maximum potential for the company's benefit (Gil, 2007). In this sense, the author defines performance as "the way in which an employee performs the functions and tasks assigned to him/her, in accordance with the mission and objectives set by the company and demonstrates in the exercise of his/her functions that he/she has the skills required for the position he/she performs" (Gil, 2007; p. 91). In addition, Castro \& Martínez (2014) state that due to the socioeconomic transformations that have been experienced, this time has been defined as the "age of intangibles", which means that value is no longer determined by the accumulation of money and other tangible assets, but by the ability of organizations to generate more value from the assets that make up social capital (values, norms, attitudes, networks, among others). They understand that the development of social capital positively impacts the well-being and competitiveness of the organization. The researchers conclude that a company with a healthy organizational culture provides a learning environment that influences organizational effectiveness, agreeing in this sense with Gil (2007), when he argued about the importance of developing human capital in order to optimize its performance.

On the other hand, Maxham, Netemeyer \& Lichtenstein (2008) state that it is only when people begin to experience closeness and significance with their organization that they express energy, enthusiasm and passion in the workplace; and when this happens, it results in higher productivity and better results. Heskett (1994) states that success in organizations that offer products or services depends, to a large extent, on the satisfaction of the customer who consumes those products or services. An extremely important part of customer satisfaction is customer loyalty, which is obtained through the quality of the service received when meeting their expectations. This is why it is very important to develop employees so that their performance is effective and they are able to meet customers' service expectations. In this sense, Heskett (1994) together with several collaborators, developed a model that explains the relationship between these variables: profit, customer loyalty, and customer satisfaction, where customer satisfaction and customer loyalty are considered external outcomes affected by the productivity (performance) of the company's employee (Heskett, 1994 and Maxham et al., 2008).

\section{CUSTOMER SATISFACTION AND LOYALTY, AS COMPONENTS OF EXTERNAL SERVICE EXPRESSED BY CUSTOMERS}

Undoubtedly, in retail companies, it is essential, above all, to provide good customer service for the prosperity of any business, company or organization. Customer satisfaction is obtained when the quality of the service offered exceeds the customer's expectations, especially in service companies. Dehghan (2012), conducted a study through which an analysis of the factors that must be addressed to achieve customer 
satisfaction is generated, among these are: technical support, reliability, courtesy, responsibility, and empathy. One of the factors related to customer service is customer loyalty or reliability. According to Setó (2003), in a difficult and competitive market, companies should have as one of their main objectives to retain their customers, providing them with the service they expect and that will earn their loyalty. Vecino (2013) highlights what he considers to be the three key aspects to obtain a solid organizational strategy, which allows to obtain customer loyalty, which provides a competitive advantage in a market in difficult times. The first aspect is to attract customers, the second is to keep them, and the third is to develop them. To achieve this, the design of the service and the service provider must be present in the equation; the design refers to the product, facilities and technology available, while the service provider is the one who executes the strategy designed to meet the customer's expectation. Vecino (2013) concludes in his study that "the experience that the customer wants to repeat" is achieved when these two elements are satisfactorily combined: good service design and excellence in the service provider, which allows the customer to evaluate the quantity, quality and service costs, as well as the knowledge and charisma of the service provider.

In addition to the above, Carreón's study (2014) found a figure that should be taken into consideration by entrepreneurs and retail store owners: $72 \%$ of retail customers are lost due to indifference or poor attention from employees. Therefore, he states, customers are willing to sacrifice price and convenience to obtain a satisfactory service, so they will even pay more for a product or service or go further to receive the service quality they expect. This is why it is of utmost importance to generate strategies, not only to attract new customers, but also to retain existing ones through an excellent service quality. In this sense, he concludes that exceeding customer service expectations is a step ahead of competitors. Carreón (2014) states that among the factors associated with good customer service are: knowing the customer perfectly, the treatment inside the facility, and having contingency plans in the event of an adverse situation such as the non-availability of a product, or changes and returns by the customer.

\section{CONCEPTUAL FRAMEWORK AND PROPOSED MODEL}

In order to carry out this research and with the purpose of finding an answer to the initially proposed objectives, Mitroff and Alpaslan's (2009) theory on spirituality in business administration is reviewed in depth. The reason that gives relevance to this theory is that most of the authors that were consulted, consider these two theoreticians as a reference for their analysis, since they were the precursors of the spirituality concept in the workplace, by publishing one of the first empirical studies on this topic (Jiménez, 2015). In the years that proposed this reference model, Mitroff and Alpaslan (2009), defined spirituality perceived as "whole beings", which refers to the basic feeling of being fully connected with oneself, with others and with the entire universe (Jiménez, 2015). The study results indicated that employees associated with faithbased organizations were able to bring more of their "whole beings" to work, which allowed them to develop creativity, emotions and intelligence on a larger scale, resulting in better performance or higher productivity (Jiménez, 2015).

For this research, we will therefore adapt the model proposed by Jiménez (2015) in his study: Spiritual capital as an intangible asset that adds economic value to companies in Puerto Rico: a descriptive study of the perception of professionals who offer accounting services. This model includes both spirituality at work and employee perceptions of customer satisfaction and loyalty. Jiménez's model is a combination of the Causal Model of Spiritual Environment and its Impact on Customer Experience proposed by Padney, Gupta, \& Arora (2009) along with Heskett's (2009) Service-Benefit Chain Model. The principles of the first model aim to: trace the conceptual bases of the spirituality notion in different streams of knowledge, develop an instrument to measure spirituality in the organization and company environment, and test the impact of the spiritual environment on employees' experience of customer service. The second integrated model is Heskett's (1994) model known as the Service-Benefit Chain. Jiménez (2015) explains that this model associates the variables of profitability and business profits with service quality, employee satisfaction and productivity, and customer satisfaction and loyalty. 
In addition to the previous academic contributions, and with the purpose of answering the third proposed objective, an adaptation was made to the model Relationship between the spiritual environment and the profitability of companies by Jiménez (2015), and the following proposed model was generated. As described in the theoretical foundations, this theoretical proposal is an adaptation of the three previous works described above. (Heskett, 2009; Jiménez. 2015 and Pandey et al., 2009). The chart below explains the origin of each theory and how they are combined in order to explain the concept of spirituality at work and its effects on employee satisfaction, productivity and commitment, and considering that spirituality explains employees' perception of customer satisfaction and loyalty. Therefore, the proposed model suggests that, in order to evaluate spirituality in the workplace, seven basic elements proposed by previous studies should be considered: the optimism of employees, the enjoyment of their work, the integrity of workers in a workplace, the employee's search for transcendence, respect for diversity, the community sense, and harmony with oneself and with the worker's environment (see figure \#1).

\section{FIGURE 1 \\ PROPOSED MODEL FOR MEASURING THE EFFECTS OF SPIRITUALITY ON THE INTERNAL SERVICE QUALITY AND THE PERCEPTION OF THE EXTERNAL SERVICE VALUE}

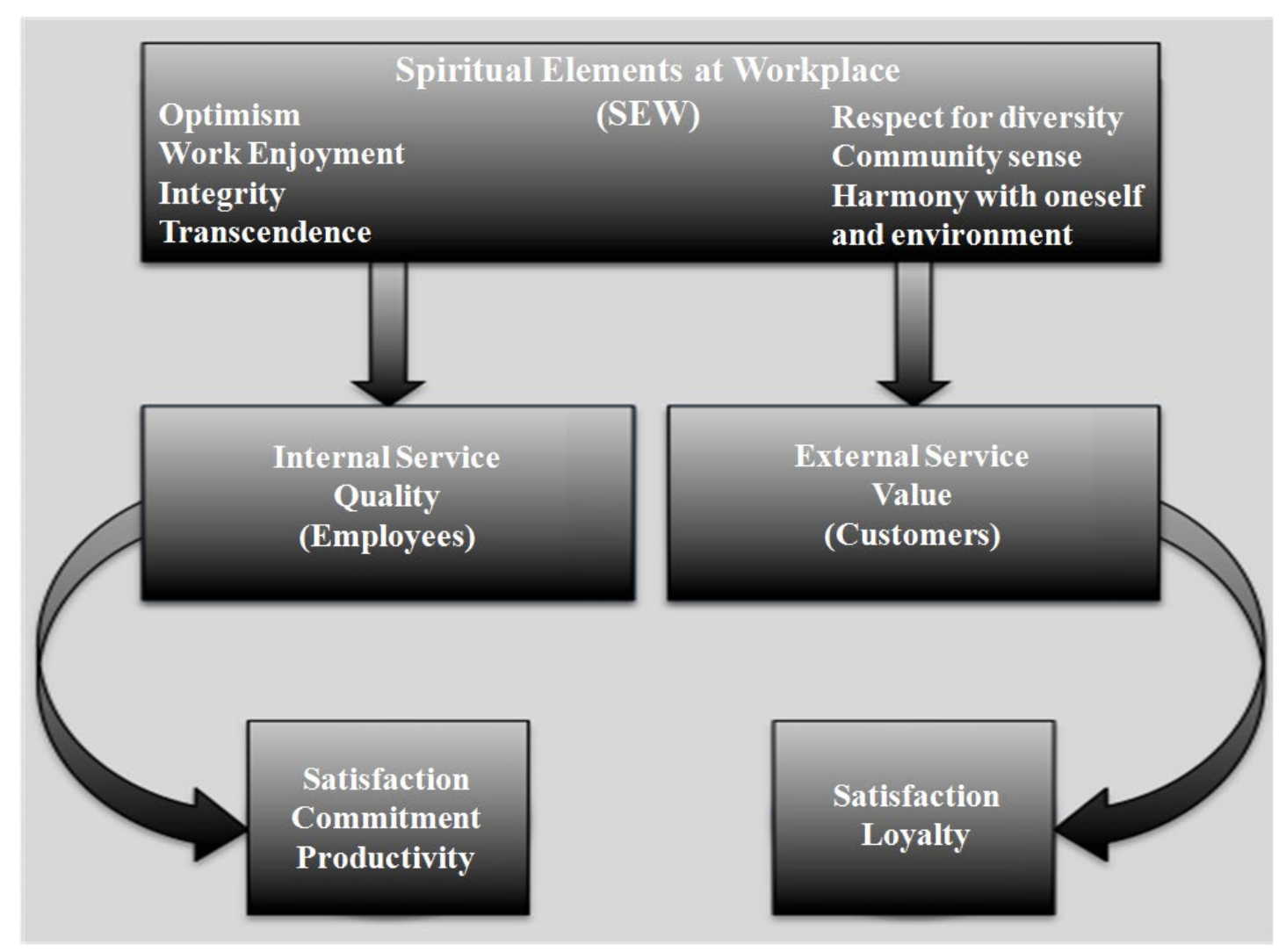

Developed by the author.

\section{METHODOLOGY}

This study used a quantitative approach, in which two hypotheses were developed and tested through data collection and statistical analysis. The design of this work is non-experimental-transectional, as there was no deliberate manipulation of variables, but rather phenomena were observed and analyzed, and data were collected at a single point in time (Hernández et al., 2014). The scope of this research was exploratory and causal. The first objective was approached in an exploratory way since there is not a lot of information 
about spirituality at work and its effects on the Internal Service quality and the perception of External Service Value, specifically in Puerto Rico. On the other hand, in order to solve objectives 2 and 3, these objectives were focused on a quantitative approach, but with a causal scope, since the aim was to analyze and quantify the effect between the study variables. These two objectives give rise to the following working hypotheses:

\section{First Hypothesis}

Based on the second research objective, the following hypothesis has been generated:

\section{Null Hypothesis}

$\boldsymbol{H}_{0} \boldsymbol{A}=$ The higher the levels of spirituality practiced in the workplace, the lower the internal service quality of retail company employees (employee satisfaction, productivity and commitment).

\section{Alternative Hypothesis}

$\boldsymbol{H}_{1} \boldsymbol{A}=$ The higher the spirituality practiced in the work area, the better the internal service quality of the retail company employees (employee satisfaction, productivity and commitment).

\section{Second Hypothesis}

Based on the third research objective, the following hypothesis has been generated:

\section{Null Hypothesis}

$\boldsymbol{H}_{0} \boldsymbol{B}=$ The higher the spirituality practiced in the workplace, the lower the perception of the external service value of the retail company employees (customer satisfaction and loyalty).

\section{Alternative Hypothesis}

$\boldsymbol{H}_{1} \boldsymbol{B}=$ The higher the spirituality practiced in the workplace, the higher the perception of the external service value of the retail company employees (customer satisfaction and loyalty).

\section{INSTRUMENTATION AND WORK SAMPLE}

A questionnaire with thirty premises developed by the researchers was used as an instrument for data collection. This questionnaire was previously validated by three university professors specializing in the subject, and then validated for internal consistency. The questionnaire developed for this research process has two parts: the first part collects the sociodemographic data of the participants, while the second part was designed with the purpose of analyzing the effect of spirituality on the internal service quality and on the employees' perception regarding the external service value. Accordingly, this second part includes three sections, each of which addresses each of the research objectives. The reactive questions were designed using a seven-point Likert scale to answer the questions as follows: completely agree (7), strongly agree (6), agree (5), neutral (4), disagree (3), strongly disagree (2), completely disagree (1). The logistical procedure for data collection was under the strategy of delivering the questionnaire directly to the participants, after obtaining the authorization of the manager or person in charge of the company.

The analysis sample for this research was calculated from a total population of employees of a commercial center in the eastern area of Puerto Rico, which at the time of data collection had a population of 365 employees. From this population, a probability sample of 187 participants was calculated, considering a 5\% margin of error and a confidence level of $95 \%$. Despite providing 200 questionnaires, for reasons of participation, we were able to collect a total of 131 questionnaires answered, thus obtaining $70 \%$ of the calculated sample. 
Once the data were collected through the questionnaire, we proceeded to analyze the results, which are shown in the following section.

\section{RESULTS AND ANALYSIS OF THE RESEARCH RESULTS}

\section{Demographic Data of the Sample}

This first part of the results shows the analysis of the sociodemographic data of the participants retrieved from the questionnaires. These include: gender, age, academic preparation, years of work experience in retail companies and position held.

\section{Gender and Age of Participants}

In terms of gender, out of a total of 131 employees who participated in the study, the most were men with a total of 91 for $69 \%$ of the sample; while the female gender, on the other hand, accounted for 40 participants, which represents $31 \%$ of the sample. Regarding age, most of the participants were in the 1825 age range with $37 \%$ (48 participants), followed closely by the $26-35$ age range with $33 \%$ (44 participants). A total of 25 participants, or $19 \%$, were in the $36-45$ age range. $8 \%$ of the sample are between 46 and 55 years old (10 participants), and only 4 participants are 56 years old or older, for a total of $3 \%$ of the sample. About $70 \%$ of the study participants are between 18 and 35 years old and $30 \%$ of the respondents are older than 36 years old.

\section{Academic Preparation and Work Experience}

This study found that the vast majority (58\%) have a bachelor's degree or more than that, therefore, it is stated that the sample mostly has a higher level of education; therefore, $42 \%$ of the sample has a level of academic preparation lower than a bachelor's degree. When asked about years of work experience, it was found that $43 \%$ of the participants have 5 years or less experience in retail companies (57 participants) and $57 \%$ of the sample has more than 5 years of work experience. These demographic data show that the majority of the sample is highly educated and knowledgeable about their work in the retail sector.

\section{SPIRITUALITY LEVEL IN RETAIL COMPANIES IN PUERTO RICO}

To find the answer to the first objective, the frequency analysis technique was used; therefore, the averages obtained from the questionnaires for each of the spirituality elements used in the questionnaire were used to generate a Radar Chart, which is useful because it allows visualizing the current state of each element in comparison with the ideal state. Therefore, in order to evaluate spirituality, seven elements of spirituality related to the work area were considered, which are derived from the model proposed by Pandey, et al. (2009), these elements were: 1) optimism; 2) work enjoyment; 3) integrity (probity, honesty, righteousness); 4) respect for diversity; 5) harmony with oneself and the environment; 6) community sense (caring for colleagues, bosses, subordinates, customers, social and natural environment) and 7) transcendence (principles, motivations and interests that go beyond oneself). The final results are displayed in Figure \# 2 below: 


\section{FIGURE 2 \\ LEVELS OF THE SPIRITUALITY ELEMENTS IN THE RETAIL LABOR AREA IN PUERTO RICO}

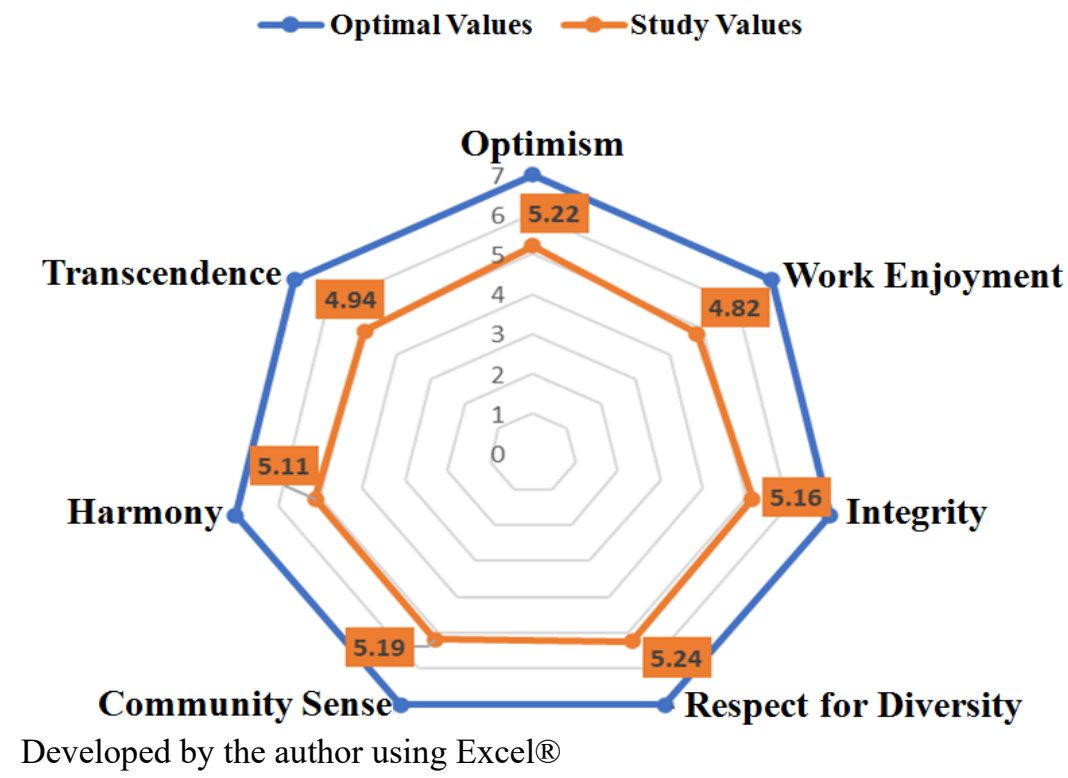

According to the previous graph, it can be seen that all the spirituality elements related to the work area of retail workers in PR are above the neutral value, which in this case would be 4, and close to the ideal level, which as already mentioned is equivalent to point 7 of the Likert scale used in the study. The average calculated for each of the spiritual elements is greater than or close to 5. In order to obtain the ideal state of each of these elements and their relationship with the concept of spirituality at work, strategies must be created to increase their relevance until reaching the ideal point of 7 on the Likert scale.

The highest scoring element was respect for diversity with an average score of 5.24, followed closely by the optimism element which scored 5.22. These are followed by the community sense element with a 5.19 , integrity with a 5.16, and harmony with a 5.11. The remaining two elements, transcendence and work enjoyment, are below score 5 with 4.94 and 4.82 respectively. Although all the elements are above average on the value scale from 1 to 7, the last two (transcendence and work enjoyment) are the farthest from the ideal state or level (7).

\section{STRUCTURAL AND EXPLANATORY VALIDITY OF THE PROPOSED STRUCTURAL EQUATION MODELING}

For solving objectives 2 and 3 of this research, structural equation modeling was used via the second order partial least square -SEM-PLS technique as shown in chart \# 3 below. This research model is made up of three constructs, which in this model are known as Latent Variables: a) spirituality elements at work, b) internal service quality, and c) external service value. From the theoretical review, the first construct is formative in nature and the other two constructs are reflective. A construct is formative when the indicators are those that cause or give rise to the construct (Castro-Gonzáles \& Medina, 2017 and Hair, 2019); in this case, the indicators: optimism, work enjoyment, integrity, respect for diversity, harmony, community sense and transcendence are those that form the construct of spirituality at work (causal). The constructs internal service quality and external service value are reflective, since their indicators are a reflection of the construct to which they are linked (effect), and it is the construct that gives rise to what is observed (indicators). The internal service quality indicators are: employee satisfaction, productivity and commitment, while the external service value indicators are: customer satisfaction and loyalty. In this first 
part, then, the structural validity of the model must be determined before discussing its results. This is a big advantage of structural equation modeling, because it does not only analyze the results, but evaluates the model from its structural validity and then by its explanatory nature of the model (Castro-Gonzáles, \& Medina 2017). For this reason, in order to evaluate their structural validity, they are worked according to the type of variables to be used. The indicators used to measure spirituality and its effects on internal service quality and external service quality are formative. However, in order to measure the quality of internal and external service, indicators of a reflective nature were used, as can be seen in the results of the model shown in chart \# 3 below.

\section{Validity of Reflective Constructs}

The reason why the types of constructs are classified, is because the processing of their reliability measures are different; this is why we start working with the reflective constructs, using for this purpose the SmartPLS ${ }^{\circledR}$ program, we find their internal validity of the reflective constructs, by calculating their average variance extracted (AVE) which in this case is greater than 0.50 , which means that more than $50 \%$ of the construct variance is due to the variability of its indicators (Castro-Gonzáles \& Medina, 2017; Triguero et al. 2012). In this sense, the internal service quality construct obtained 0.579 , which means that $58 \%$ of the Internal Service Quality is explained by the variability of the elements used. The external service value construct obtained a 0.673 , which implies that $67 \%$ of this construct's variance is explained by the variability of its determinants used. The internal measure of construct reliability was also performed, where according to Hernández-Díaz, et al., (2020) and Hair (2012) recommend that acceptable values of Cronbach's alpha are those above 0.7. In this case, according to table \#1 all values are greater than this recommended minimum. Only Customer Loyalty has a value of 0.64 but given the model's complexity and with a value close to 0.70 , the model as a whole expresses what the researchers want to find.

It is important to mention that the customer satisfaction construct is the one that obtained the highest internal validity score with $91 \%$. According to the literature it is recommended that this value be analyzed together with Rho_A, and in this case all values are greater than the minimum 0.70 , so the model structurally has a high reliability level. Finally, the coefficient of determination or $\mathrm{R}^{2}$ was measured. According to Castro-Gonzáles \& Medina (2017) and Triguero et al., (2012) this metric, is called the coefficient of determination and determines in other words the reliability level of the model. As can be concluded from chart \#1, all the values have a significant $\mathrm{R}^{2}$ level. Customer satisfaction (0.912), followed by employee productivity (0.902), and employee satisfaction (0.904) stand out among the most important values. This statistical value is equivalent to the value of the coefficient of determination in multiple linear regressions. Therefore, we can state that the model has a very high level of structural validity and express reliability. The following table \#1 shows the results discussed in detail in this section.

TABLE 1

\section{CALCULATION OF FEASIBILITY AND RELIABILITY VALUES OF REFLECTIVE CONSTRUCTS}

\begin{tabular}{lrrrrrr}
\hline \multicolumn{1}{c}{ Variables } & $\begin{array}{c}\text { Cronbach's } \\
\text { Alpha }\end{array}$ & \multicolumn{1}{c}{ Rho_A } & $\begin{array}{c}\text { Composite } \\
\text { Reliability }\end{array}$ & $\begin{array}{c}\text { Average Variance } \\
\text { Extracted (AVE) }\end{array}$ & R Square & $\begin{array}{r}\text { R Square } \\
\text { Adjusted }\end{array}$ \\
\hline CAL_SER_INT & 0.938 & 0.941 & 0.947 & 0.579 & 0.591 & 0.588 \\
LEALTAD_CLIEN_ & 0.635 & 0.712 & 0.840 & 0.726 & 0.727 & 0.724 \\
LEALTAD_EMPL & 0.813 & 0.829 & 0.878 & 0.646 & 0.881 & 0.880 \\
PRODUCT-EMPL & 0.849 & 0.861 & 0.894 & 0.631 & 0.902 & 0.902 \\
SATISF_CLIEN & 0.912 & 0.913 & 0.945 & 0.851 & 0.913 & 0.912 \\
SATISF_EMPL & 0.829 & 0.835 & 0.887 & 0.665 & 0.905 & 0.904 \\
VAL_SER_EXT_ & 0.870 & 0.886 & 0.910 & 0.673 & 0.492 & 0.488 \\
\hline
\end{tabular}

Developed by the author based on SmartPLS® software output Source: SmartPLS.3®, Ringle, Wende and Becker (2015). 


\section{Validity of Formative Constructs}

In this model, the formative construct of spirituality at work was subjected to validation using the following steps: a) first, the estimated weight of its indicators is analyzed, which measures the contribution of each indicator to the variance of the latent variable (Roberts \& Thatcher, 2009). The weights of the indicators are used as evidence of construct validity; values less than $+/-0.07$, are eliminated because they do not contribute significantly to the Model (Castro-Gonzáles \& Medina, 2017 and Hair et al., 2019). Looking at the seven formative indicators of the spirituality at work construct, it is stated that they are significant and have the following order: community sense 0.185 , integrity 0.367 , harmony 0.532 , transcendence 0.151 , respect for diversity -0.173 (negative value indicating that acceptance of diversity is negative regarding spirituality), work enjoyment -0.196 and optimism 0.193 . Another step to validate a formative construct is b) to assess multicollinearity, this characteristic measures whether among the indicators there are not some pair or more of them expressing the same thing (Hair et al., 2019 and Roberts \& Thatcher, 2009). The statistical theory, proposed by Hair et al. (2019) indicates that these values are measured with the path coefficients which should not be less than 0.70 and with the variance inflation factor (VIF), which should not be greater than 5.00. In Table \# 2, in each value cell, the "path value" is presented first and in brackets and the [VIF] are shown in italics. From this table, it is found that the values for all interacting variables are adequate to support that the model has convergent validity when dealing with formative constructs. Therefore, we can state that the values found give it validity and the model is strengthened.

TABLE 2

\section{PATH COEFFICIENTS AND VARIANCE INFLATION FACTORS /VIF] OF THE FORMATIVE CONSTRUCTS OF THE MODEL}

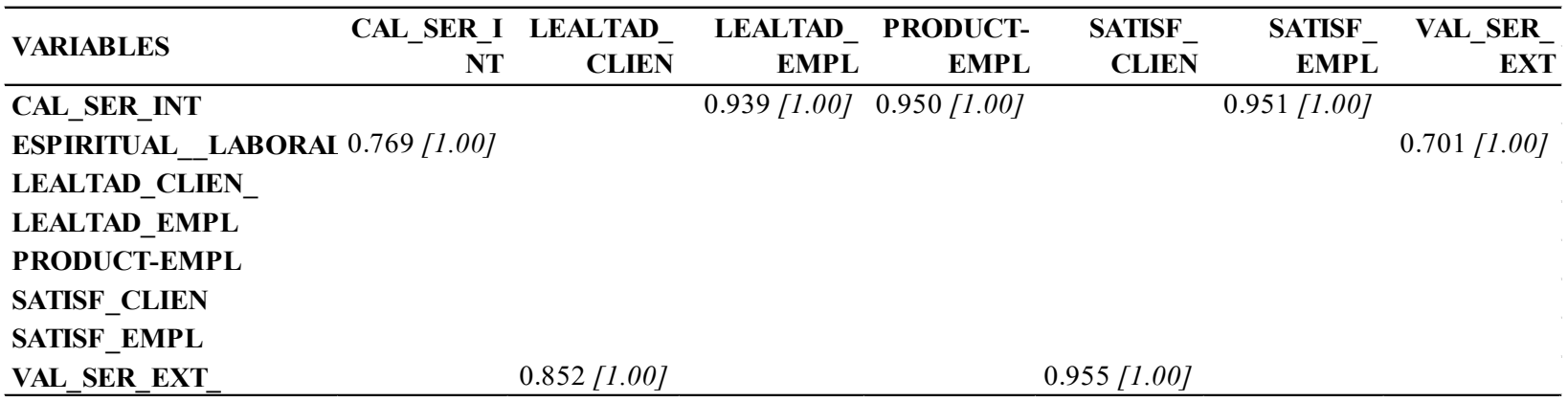

Developed by the author based on SmartPLS ${ }^{\circledR}$ software

Source: SmartPLS.3®, Ringle, Wende and Becker (2015).

\section{EFFECT OF SPIRITUALITY ON EMPLOYEE SATISFACTION, PRODUCTIVITY AND LOYALTY (INTERNAL SERVICE QUALITY)}

To find the results of objective 2, the second order Structural Equation Modeling (SEM) was used, under the "partial least squares" (PLS) statistical solution technique through the SmartPLS® program. The SEM-PLS analysis technique is a set of multiple regressions that work all relationships simultaneously, and not necessarily considering linear relationships but other types of interactions, including between variables (Castro-Gonzáles, et al., 2016). This technique not only analyzes the relationship between multiple latent variables, but also measures the weight or significance of those relationships. These models have gained interest and are increasingly used among researchers, largely because of their ability to include latent constructs under non-normal conditions and using small and medium-sized samples (Triguero et al., 2012). This method has been designed to reflect the theoretical and empirical qualities and behavior in situations with insufficient supporting theories and little available information. In the process, the model determines whether or not there is a relationship between multiple variables or constructs, making it a tool for testing or rejecting hypotheses established in a study (Hair, 2012). 
Figure \# 3 shows the results of this proposed model, corroborated by the metrics previously described. From this chart it can be concluded that the indicators proposed to measure the Workplace Spirituality of the employees interviewed all have relevance in the formation of this construct. From these indicators we can conclude that the following are more important due to their correlation values: worker harmony (0.532), integrity (0.367), optimism (0.193) and commitment (0.185). There are two indicators that have a negative correlation with the environment of spirituality that should exist in the workplace: diversity $(-0.173)$ and job satisfaction (-0.196). Another result to highlight is the effect that workplace spirituality has on the four variables used to measure the employee's Internal Service Quality. It can be seen that there is a correlation value of 0.769 for these two variables. Therefore, we can conclude that this is a high level of correlation.

\section{FIGURE 3 \\ SEM-PLS MODEL, RELATIONSHIP BETWEEN CONSTRUCTS AND INDICATORS}

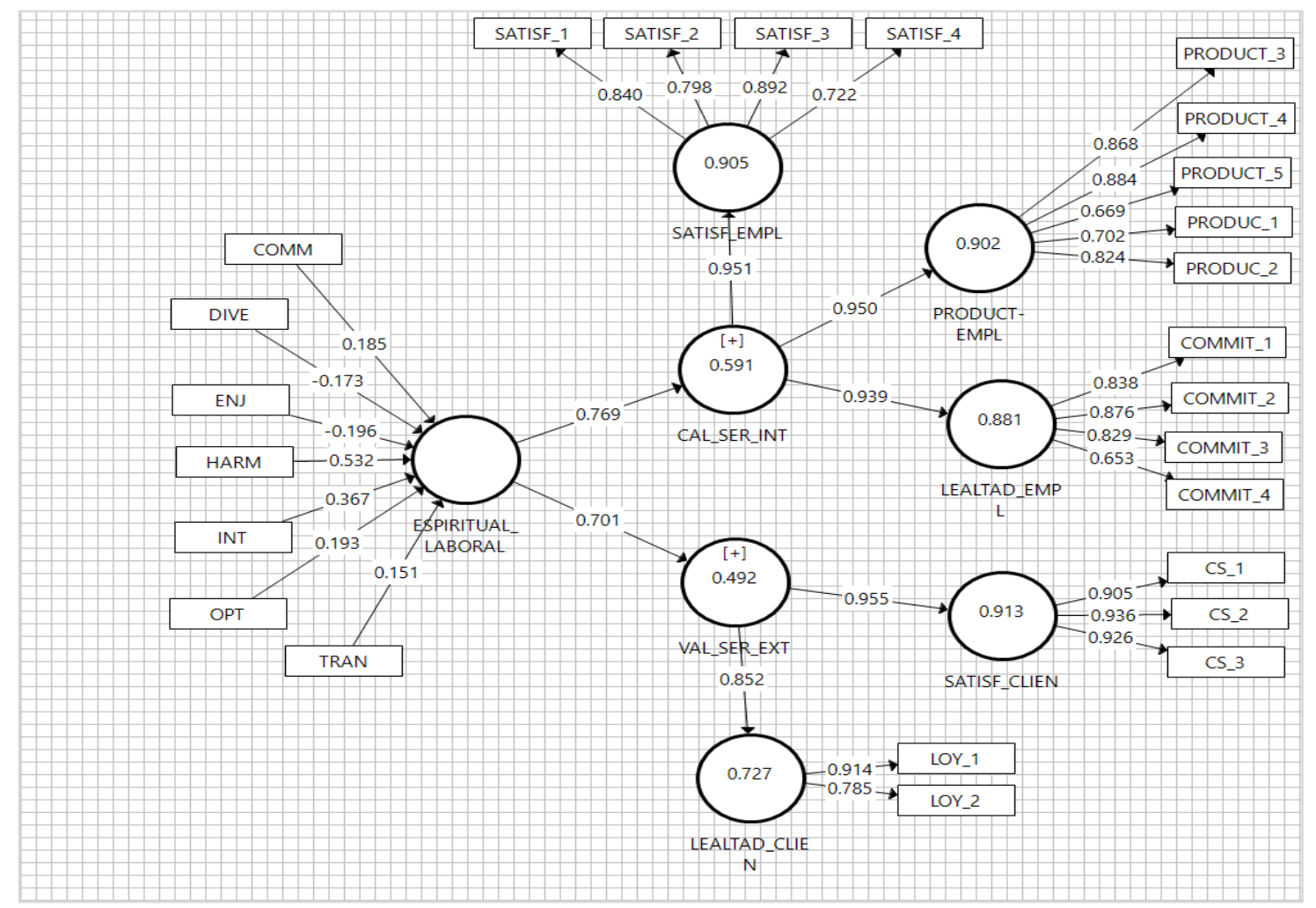

Developed by the author using Smart-PLS ${ }^{\circledR}$

Source: SmartPLS.3®, Ringle, Wende and Becker (2015).

When analyzing the effect of workplace spirituality on customers' external Service Value, this also has a relevant importance since its correlation value is 0.701 . Another result that deserves to be highlighted is that workplace spirituality has a positive effect on employee productivity at a very relevant level of 0.950 ; similarly, workplace spirituality has a very important positive effect on employee loyalty with a correlation value of 0.939 and on employee satisfaction with a value of 0.951 . Given that the $\mathrm{R}^{2}$ values of these constructs are at a very high level, we conclude the following: When observing the $\mathrm{R}^{2}$ of Employee Satisfaction which is 0.905 ; this means that maintaining positive environments where labor spirituality prevails in the work facilities, will be reflected in a higher level of employee satisfaction, explaining $90.5 \%$ of this very important element. If we observe on the other hand the $\mathrm{R}^{2}$ of employee productivity (0.902) we can conclude that an optimal work spirituality environment will have an effect in improving employee productivity by $90.2 \%$. And finally, when we analyze employee loyalty according to its $\mathrm{R}^{2}(0.881)$, we 
conclude that adequate work spirituality environments in employees have an effect of $88.1 \%$ in achieving greater employee loyalty with the company.

\section{Effect of Employee Spirituality on Customer Loyalty and Satisfaction (External Service Quality)}

From the previously detailed chart \# 3, which corresponds to the "output" of the SmartPLS® program, the formative construct External Service Value is explained by $49.2 \%$ of the variability of the components of the spiritual environment in the workplace. Now looking at their correlation values, the correlation is high because it has a value of 0.701 . On the other hand, when analyzing the $\mathrm{R}^{2}$ of the two formative components of this second-order construct: customer satisfaction and customer loyalty, it is observed that these values are 0.913 and 0.727 . These are very important and significant values regarding the reliability. In other words, we can state that work spirituality in the workplace has an importance in improving the level of customer satisfaction by $91.3 \%$ when there are workers with levels of spirituality who have attended to them. In addition, when looking at the level of customer loyalty and considering the $\mathrm{R}^{2}$, it is then stated that the employees' work spirituality levels explain $72.7 \%$ of the improvement in customer loyalty. That means that we will have the probability that the customer will come back to us possibly $73 \%$ of the time if he/she has been served by workers who practice high levels of spirituality.

\section{Hypothesis Tests of the Model}

Finally, in order to perform the hypothesis tests proposed in the model, chart \# 4 is provided below, in which the $t$-values of the model are calculated. Thus, when analyzing the " $t$-value" for these two variables, it is reasserted that spirituality in the workplace positively affects the internal service quality, obtaining a value of 20.142 (the minimum value is 1.96), so the first alternative hypothesis established is accepted, in this way we accept the alternative hypothesis 1 and reject the null hypothesis which states that there is no positive relationship between spirituality in the workplace and the internal service quality of the employees. Therefore, the following hypothesis is accepted:

$\boldsymbol{H}_{1 A}=$ The higher the spirituality practiced in the workplace, the better the internal service quality of retail company employees, expressed in terms of improved employee productivity, improved employee loyalty and employee satisfaction in the workplace.

On the other hand, when we analyze the second working hypothesis, and according to chart \# 4 and its "t-value" we conclude that having a value of 15.095 (about 8 times greater than the minimum allowed of 1.96) therefore, the alternate hypothesis is accepted and the null hypothesis is rejected again, then we can state that it is correct to affirm that:

$\boldsymbol{H}_{1 B}=$ The higher the spirituality practiced in the workplace, the higher the perception of the external service value of retail company employees, expressed in higher levels of customer satisfaction and increased customer loyalty to the commercial services company. 
FIGURE 4

MODEL BOOTSTRAPPING, TO DETERMINE THE T-VALUES OF THE MODEL

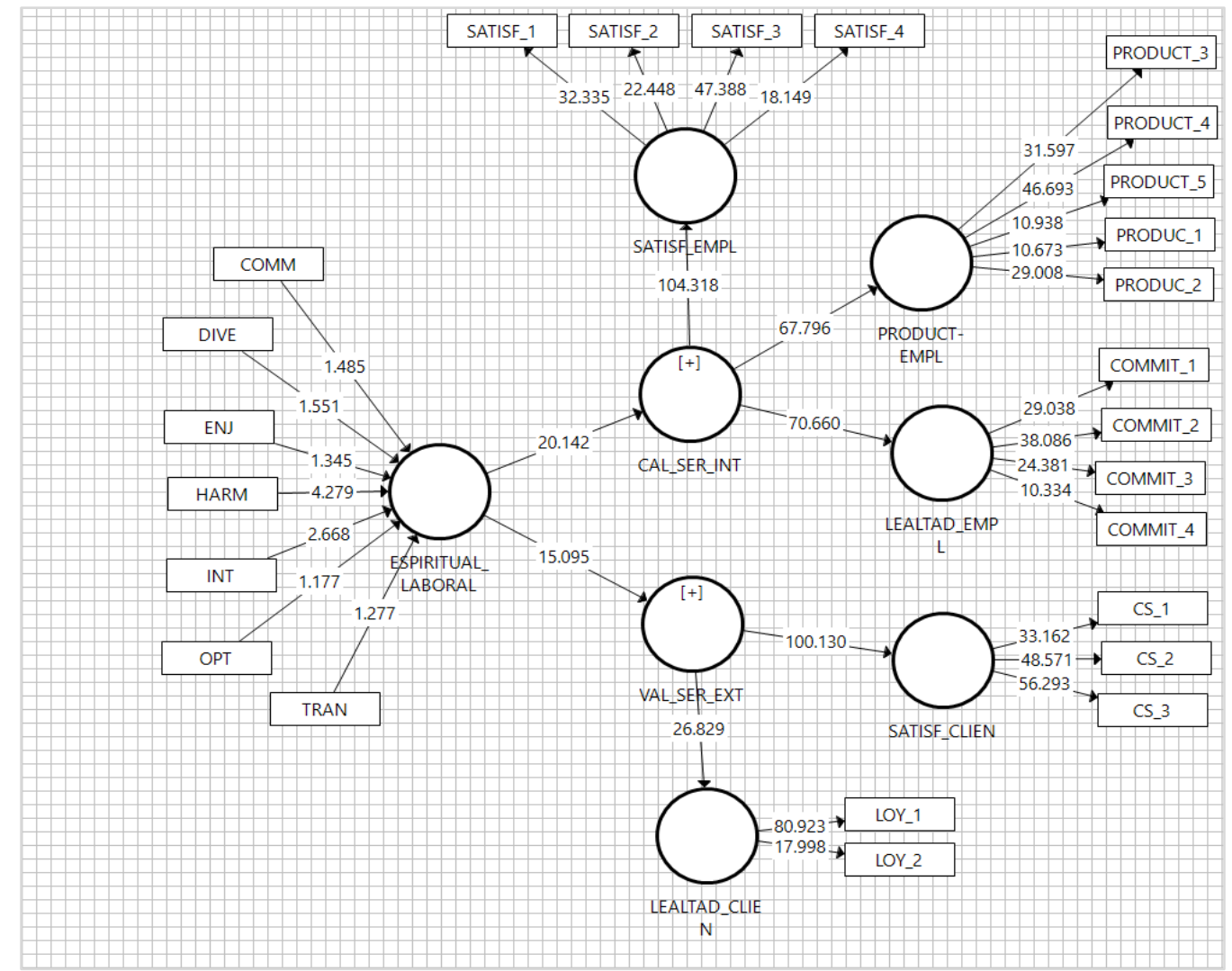

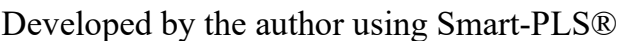

Source: SmartPLS.3®, Ringle, Wende and Becker (2015).

\section{STUDY CONCLUSIONS}

The first important conclusion of this study is that the majority of retail company employees belong to the male gender $(69 \%)$, these respondents are between 18 and 35 years old $(70 \%)$, the respondents who answered the proposed questions have a high school degree or less $(86 \%)$, hold the position of part-time employees $(46 \%)$, and have 5 years or less of work experience in retail companies $(43 \%)$. So, we can conclude that the labor force of retail companies in Puerto Rico is composed, primarily, of young and middle-aged adults whose academic preparation does not exceed a high school degree, and who work mostly as part-time employees.

Regarding the spirituality level of Puerto Rican workers, we can conclude that the choice of considering seven elements to measure labor spirituality was correct: optimism, enjoyment, integrity, transcendence, respect for diversity, community sense, harmony with oneself and with the environment. On the other hand, it is concluded that all of them, in effect, give rise to the latent variable of spirituality related to the workplace. When analyzing the values individually by element, it was found that respect for diversity resulted with the highest score with an average of 5.24, while the lowest score was work enjoyment with an average of 4.82 . However, all elements were above or very close to the average level. I state that the spirituality levels of the employee interviewed are higher than average.

The third conclusion of this study is that the SEM-PLS second-order model, used through the SmartPLS ${ }^{\circledR}$ program, provides us with a tool to analyze the validity of the indicators or elements proposed to make up the latent variable of spirituality at work. After calculating the estimated weight of all the 
indicators, it is concluded that there was a good selection of indicators and that they objectively represent the construct of spirituality at work. The indicator with the highest weight was harmony at work with 0.532 , followed by integrity (0.367), although this study found that there are two indicators that have a negative correlation with spirituality: work enjoyment (-196) and acceptance of diversity (-0.173), perhaps the explanation for these values has to do with the nature of Puerto Rico being a Latin and Caribbean country exposed to beaches of great beauty and where conservative criteria are still prevalent regarding the issue of diversity.

The fourth important conclusion of this research was that spirituality in the workplace positively impacts the internal service quality. Therefore, this finding implies the importance that retail workers should be provided with a spiritual workplace in order to have a $90.2 \%$ productivity improvement effect, which will also be reflected in an $88.1 \%$ improvement in employee loyalty and probably a $90.5 \%$ improvement in work satisfaction. This assertion is corroborated because the first alternative hypothesis of the study was approved with a considerable level of statistical significance $(t$-value $=20.142)$.

The last important conclusion of this research is that employees' workplace spirituality will have a positive effect on external service value. Given the fact that this is reflected on two constructs we can state that workplace spirituality will have a positive effect on customer satisfaction at a level of $91.3 \%$ and an improvement in customer loyalty at a perceived improvement of $72.7 \%$ likelihood that customers will return again to this commercial center and become loyal customers. These assertions as well as the previous conclusions are corroborated when it is verified that the $t$-value for this second hypothesis obtained a value of 15.095 considering that the minimum value to accept a working hypothesis is 1.96 . Therefore, we can state that there is a significant relationship between employee spirituality and customer satisfaction and loyalty (external service value).

\section{STUDY LIMITATIONS}

The study's limitations include, in the first place, the lack of information regarding the concept of spirituality related to the workplace, since it has been a little-studied topic, especially in Puerto Rico. This not only refers to the fact that there are not enough studies on the island available to support the theoretical part of this research, but the real limitation lies in the fact that the participants may not have answered the questionnaire taking into consideration the concept of spirituality at work as it is defined in the literature, but that their answers may have been strongly influenced by their personal definition of what spirituality is.

Due to the fact that the concepts of spirituality and religion have been closely linked throughout the ages and, despite including as part of the questionnaire a definition of spirituality where it is stated that spirituality or religious values do not imply any affiliation to religious institutions, participants may have completed the questionnaire under the perception that both concepts have the same meaning.

Given the fact that this study used data from retail company employees, as in any other business, and the perception that time represents money; in that sense, for some employees and/or managers, using time in the workplace to complete a questionnaire that does not directly benefit them was not viable, and for that reason, $70 \%$ of the calculated sample participated in the study.

\section{Practical Implications}

The spirituality levels are so important for employees in Puerto Rico and around the world, especially in Latin American countries, where it is important that entrepreneurs and business owners take into account the results of this research because by working to efficiently address the issue of spirituality in the workplace, they will certainly have a significant increase in their levels of productivity, loyalty and satisfaction of their employees, who are the most important assets of the companies.

On the other hand, implicitly, the results of this research have shown that by encouraging and supporting the elevation of the spirituality levels of their employees in the workplace, service organizations will directly benefit from greater customer loyalty, as well as greater satisfaction with their services and 
assistance received. Therefore, it would improve the level of marketing with satisfied and loyal customers which is the best marketing technique that exists by having a satisfied and loyal customer.

\section{ACKNOWLEDGEMENT}

Translated \& edited by American Publishing Services (https://americanpublishingservices.com/).

\section{REFERENCES}

Argandoña, A. (2014). ¿Qué es la espiritualidad en el trabajo? IESE Business School, University of Navarra. Retrieved from http://blog.iese.edu/antonioargandona/2014/01/13/que-es-laespiritualidad-en-el-trabajo/

Carreon, A. (2014). La importancia del servicio al cliente en retail. Revista Merca 2.0. Retrieved from http://www.merca20.com/la-importancia-del-servicio-al-cliente-en-retail/

Castro, N.E., de la Garza Martínez, E.I., \& Lugo, A.I. (2014). Generación de capital Social a partir de la eficacia, la cultura y el aprendizaje organizacional: Un estudio correlacional. Revista Internacional Administración \& Finanzas, 7(1), 67-78. Retrieved from http://search.proquest.com/docview/1445268562?accountid=130249

Castro-Gonzáles, S., \& Medina, J. (2017). Economic Crisis's influence over the Quantification of Puerto Rico's Shadow Economy: Parsimonious Econometric Proposal. Journal of Applied Business and Economics, 19(8), 48-62.

Castro-Gonzáles, S., Espina, M., \& Tinoco, R. (2016). Strategies and Competitiveness for Emerging Countries: A Comparative Study Among Three South-American Countries. International Journal of Emerging Markets, 12(1), 125-139.

Chawla, V., \& Guda, S. (2013). Workplace Spirituality as a Precursor to Relationship-Oriented Selling Characteristics. Journal of Business Ethics, 115(1), 63-73. https://doi.org/10.1007/s10551-012$1370-y$

Counted, V., Possamai, A., \& Meade, T. (2018). Relational spirituality and quality of life 2007 to 2017 : An integrative research review. Health and Quality of Life Outcomes, 16(1), 1-19. https://doi.org/10.1186/s12955-018-0895-x

Damiani, M. (2016). Espiritualidad en el trabajo. Inspirulina. Retrieved from http://www.inspirulina.com/espiritualidad-en-el-trabajo.html

Daniel, J.L. (2019). Trust as a Mediator of Workplace Spirituality and Job Performance. Journal of Business and Behavior Sciences, 31(2), 80.

Dehghan, A. (2012). An Investigation on the Relationship between Service Quality and Customer Satisfaction: In the Case of CCG CO. International Business Research, 5(1). http://dx.doi.org/10.5539/ibr.v5n1p3

Escobar, A., \& Viader A.M. (2013). Perfil espiritual de estudiantes universitarios de nuevo ingreso. Primera fase de un estudio longitudinal. Universidad del Este, Recinto de Carolina.

Gil Flores, J. (2007). La Evaluación de Competencias Laborales. Universidad de Sevilla, Facultad de Educación. ISSN:1139-613X. Retrieved from http://espacio.uned.es/fez/eserv/bibliuned:EducacionXXI-2007numero10-824/Documento.pdf

Hair, J.F. (2012). PLS-SEM: Introduction and Overview. Kennesaw State University. Coles College of Business, Doctor of Business Administration.

Hair, J.F., Hult, T., Ringle, C., Sarstedt, M., Castillo J., Cepeda, G., \& Roldán, J. (2019). Manual de partial Least Square Structural Equation Modeling (PLS-SEM) (2nd Edition). OmniaScience Scholar. Sage Publishing, UK.

Hernández, S.R., Fernández, C.C., \& Baptista, L.P. (2014). Metodología de la investigación. México, D.F: McGraw-Hill Education. 
Hernández-Díaz, A., Calderón-Abreu, T., Castro-Gonzáles, S., \& Portales-Derbez, L. (2020). Exploring the sustainability of SMEs: The Puerto Rican case. Environment, Development and Sustainability, pp. 1-22. https://doi.org/10.1007/s10668-020-00960-2

Heskett, J.L. (2009). Creating Economic Value by Design. International Journal of Design, 3, 71-84.

Jiménez Martínez, M. (2015). Capital espiritual como activo intangible que añade valor económico a las empresas de Puerto Rico: Un estudio descriptivo de la percepción de los profesionales que ofrecen servicios de contabilidad.

Maxham, J.G., Netemeyer, R.G., \& Lichtenstein, D.R. (2008). The Retail Value Chain: Linking Employee Perceptions to Employee Performance, Customer Evaluations and Store Performances. Marketing Science, 27(2), 147-167. doi:10.1287/mksc.1070.0282

Mitroff, I., \& Alpaslan, C. (2009). A spiritual audit of corporate America: Ten years later (spirituality and attachment theory, an interim report). Journal of Management. Spirituality and Religion, pp. 2741. $10-1080 / 14766080802648698$

Padney, A., Gupta, R.K., \& Arora, A.P. (2009). Spiritual Climate of Business Organizations and Its Impact on Customers' Experience. Journal of Ethics, 88, 313-332. https://doi.org/10.1007/s10551-008-9965-z

Pérez Santiago, J.A. (2007). Estudio exploratorio sobre el tema de la espiritualidad en el ambiente laboral. Anales de Psicología, 23(1), 137-146.

Ringle, C.M., Wende, S., \& Becker, J-M. (2015). SmartPLS 3. Boenningstedt: SmartPLS GmbH.

Roberts, N., \& Thatcher, J.B. (2009). Conceptualizing and Testing Formative Constructs: Tutorial and Annotated Example. Ther Data Base for Advance in Information Systems, 40(3), 9-39.

Robles, E. (2011). Implicaciones de la espiritualidad en la administración de empresas. Inter Metro Business Journal, 7(1), 29-57.

Rozitchner, A. (2012). ¿Qué es la espiritualidad? La Nación. Retrieved from http://www.lanacion.com.ar/1506242-que-es-la-espiritualidad

Sant-Rajinder S.J. (2010). ¿Qué es la espiritualidad? Sendero Espiritual. Retrieved from $\mathrm{http}: / /$ senderoespiritual.com/qu-es-la-espiritualidad/

Setó Pamies, D. (2003). La fidelidad del cliente en el ámbito de los servicios: Un análisis de la escala "intenciones del comportamiento". Universidad Rovira I Virgili. Investigaciones Europeas de Dirección y Economía de la Empresa, 9(2), 189-204. ISSN: 1135-2523

Triguero, R., Peña-Vinces, J., González-Rendon, M., \& Sánchez-Apellaniz, M. (2012). Human Resources Management Practices Aimed at Seeking the Commitment of Employees on Financial and NonFinancial (Subjective) Performance in Spanish Firm: An Empirical Contribution. J. Econ. Finance Adm. Sci., 17(32).

Vecino, J.M. (2013). El diseño del servicio como estrategia del éxito empresarial. deGerencia. Retrieved from http://www.degerencia.com/articulo/el-diseno-del-servicio-como-estrategia-del-exitoempresarial

Vilaca Tavares, I.M. (2012). Espiritualidad organizacional y capital psicológico: El papel del liderazgo auténtico. Universidad de Extremadura, Departamento de Psicología y Antropología. Tesis Doctoral.

Wax, S. (2005). Spirituality at Work. Good Work: Project Report Series. N.41. Harvard University. 